\title{
Financial Products Innovation and Financial Performance of Commercial Banks in Rwanda
}

\section{A Case of Investments and Mortgages Bank}

\author{
${ }^{1 *}$ Theogene Ntirenganya $\&{ }^{2 *}$ Dr. Mercyline Kamande \\ ${ }^{1 *}$ School of Business and Economics, Mount Kenya University, Kigali, Rwanda \\ ${ }^{2}$ School of Business and Economics, Mount Kenya University, Kigali, Rwanda \\ DOI: 10.29322/IJSRP.12.01.2022.p12160 \\ http://dx.doi.org/10.29322/IJSRP.12.01.2022.p12160
}

\begin{abstract}
The purpose of this study was to examine the contribution of financial innovations on financial performance of commercial banks in Rwanda using a case of Investments and Mortgages Bank. The specific objectives were to analyze the effects of internet banking, debit and credit cards, and mobile banking on financial performance of Investments and Mortgages Bank in Rwanda. Findings are helpful to illuminate the correlation between financial innovation products and the financial performance for banking institutions. Results from the present study gave useful information with suggestion of related research areas. The study applied both descriptive and correlational research designs. A sample of 193 respondents was selected from a target population of 370 using Slovene's formula. Simple random sampling technique was used to select respondents. Questionnaire and interview guide were used to gather information, while descriptive and inferential statistics helped to analyze quantitative information, but qualitative information was analyzed using content analysis. Results on internet banking show a significant relationship between availability and simplicity of ICT application and the increase in net profits since test significance of statistics has a $\mathrm{p}$ value $=0.017$. The Regression analysis shows that an improvement in internet banking through availability and simplicity of ICT application can cause an increase in net profits by 0.173 units. Results on debit and credit cards show that restraint and record keeping were significantly affecting net profits with a level of significance of 0.033 . The Regression analysis shows that an increase in debit and credit cards leads to an increase in net profits by 0.189 units. Results on mobile banking show that the increase in fund transfers between accounts and increase in deposits are significantly affecting the return on assets and operation cost with $\mathrm{p}=0.028$ and $\mathrm{P}=0.000$ respectively. The Regression analysis shows that an increase in mobile banking through transfers leads to the increase of return on assets by 0.162 units. This study recommends that more features of financial products innovations should be introduced to attract more customers in order to improve the performance. Future studies should be carried out using a deep qualitative approach in order to know costs of financial innovation products in commercial banks in order to make a comparison with the benefits.
\end{abstract}

Index Terms- Financial Product Innovations, Financial Performance, Debit and Credit Cards, Internet Banking, Mobile Banking

\section{INTRODUCTION}

$\mathrm{T}$ he challenges in banking industry are associated with sustaining client satisfaction (Nyangosi \& Arora, 2010), increase their customer base and (Santos, 2013), most importantly increase profit (Yahya, 2015). According to National Bank of Rwanda (2019), the financial sector encountered a cost increase for banks or a deterioration for the industry as a whole and inefficacy due to delay in payment using cheques and waiting time spent by customers, mistakes from traditional labor system. This leads to more complaints from clients (Ndikuriyo, 2018).

Therefore, in search of way to outstrip any form of competition for commercial banks, it is generally contended that financial innovations have been used as a suitable means by which banks may improve their performance while at the same time being able to preserve their effectiveness in the market (Muthoni, 2013; Okibo \& Wario, 2014; Tuyishime, Memba, Mbera, 2015). Despite, the pertinent role of financial innovation products on financial performance of commercial banks, insufficiently tested were carried out on these subject areas. Empirical data on financial innovation from Nyangosi and Arora (2010), Oyugi (2014), Ntuite (2015) were found inconclusive. For example Nyangosi and Arora (2010) revealed that Kenyan Commercial Banks were able to increase customer based from 23\% to 51\% in the period between 2009 and 2013 because of the adoption of financial innovation services and 
products. Meanwhile, a study conducted in Nigeria by Oyugi (2014) among financial institutions established insignificant correlations between financial innovation and financial performance. Studies on innovations and bank's performance have produced relevant findings. For example, Ntuite (2015) assessed determinants influencing the utilization of credit cards among commercial banks. The scholar revealed that managers had credit cards whereas most of middle staff and workers did not possess credit cards.

In Rwanda, studies were conducted on financial products innovation (internet banking, debit and credit cards, mobile banking), Al-Hawari, Hartley \& Ward, 2015). The researchers focused their studies on the spread and factors determining the use of financial innovation. More studies have not been carried out on the efficiency, effectiveness, adequacy, suitability and functionality of the product innovations or and their effects on marker gross, sustaining and increase of customer base, maintain effectiveness in the market, transaction and operation costs competitiveness and increase profit. It is upon this reason why the current research seeks to bridge the gap when assessing the effects of financial products innovation on financial performance of commercial banks in Rwanda using a case of Investments and Mortgages Bank?

\subsection{Research Objectives}

The specific objectives were:

i. To analyze effects of internet banking on financial performance of Investments and Mortgages Bank in Rwanda.

ii. To assess effects of debit and credit cards on financial performance of Investments and Mortgages Bank in Rwanda.

iii. To ascertain effects of mobile banking on financial performance of Investments and Mortgages Bank in Rwanda.

\section{LITERATURE REVIEW}

\subsection{Review of Empirical Studies}

Previous studies adopted various concepts to explain financial products innovation types. These are intent banking, debit and credit and mobile banking, virtual banking, remote e-banking (Shin, 2013) and technological services (Swanson \& Ramiller, 2014).

Globally, intent banking has been applied and continues to be used by banking institutions. They provide considerable benefits to banks and their customers. Technology may facilitate customers to withdrawn money at more adequate and suitable times everywhere than during banking hours at branches (Musiime \& Biyaki, 2010). In developed countries, internet banking has played an important role to the increase of financial performance of commercial banks. For example, Vijay (2014) asserted that advancement of e-banking via several e- ways more worth to clients in investment industry. Little money, suitable service, available continuous services, save the time, access to services, rapid use of this channel, quickness, suitability compatible with living conditions and safety were pertinent elements to consider in selecting internet banking (Yahya, 2015).

In Africa, Adeoti (2021) reiterated that the utilization of internet banking is more secure and suitable. The internet banking rendered the settlement of bills in banking system easy and saver. The benefits had emanated from a phenomenon growth. Meanwhile, the advantage of safe and convenience of internet was regrettably reduced by frauds that were done by plastic money. An improvement in number of customers leads to the inclination to falsified practices. The progress in using technological devices is rapidly increased and gives new channel of aggregating and analyzing data, increasing network and decreased financial resources allocated to the services provision (Mckee, 2013). Marous (2015) specified that financial firms were devoting deeply on innovation infrastructure to undertake studies and advancement in order to get additional plan abilities in house (Mills, Helms \& Bratton, 2016). They attain their clients and give them overall and specific change realizing communicating conventional services offered by banks using e-channels (Neuert, 2014). In Rwanda, few studies were conducted on internet banking (Al-Hawari, Hartley \& Ward, 2015). This research focused their studies on the spread and factors determining the used of automatic teller. But no study has been carried out on its efficiency, effectiveness, adequacy, suitability and functionality.

Globally, several empirical studies (Ngari \& Muiruri, 2014; Murayireko, 2011) were carried out regarding the credit card utilization and the success of commercial banks. Nzalu (2015) carried out a research on constraints 
encountered the development of using credit and debit cards in developed countries. The study used a sampled population of 30 clients. Information was analyzed qualitatively. This research revealed that clients did not adopt for credit cards owing to their terror, most of are challenges opposed and other terror for credit and debit cards.

In Africa, Oyugi (2014) assessed determinants of the performance of banking institutions adopting credit card sector. The research has a sample of 12 banks. The research adopted primary data by identifying views of managers using credit cards on the factors influencing its success and provide the correlations between them (Oyugi, 2014).Information from this study was analyzed in a descriptive way. The study discovered that pertinent determinants of the success for banking institutions in using e-banking.

Rajasekar (2014) investigated determinants influencing the utilization of credit cards among commercial banks. This scholar used a sample size of 23 employees and the processing of gathering information was done using questionnaires and participants was composed of $52 \%$ of men and $48 \%$ of women. It was revealed that managers had credit cards whereas most of middle staff and workers did not possess credit cards. The research revealed that determinants of using credit cards are card deception, understanding protests, criticisms. In the Eastern African countries, Swanson and Ramiller (2014) conducted a survey on credit cards and the performance of banking institutions in Kenya. The study had been carried out six banks in Migori region and has been participated in providing information. Sampled population of 120 people has been chosen among workers. Results indicated a significant connection between using credit cards and portfolio for 26 banking institutions.

Santos (2013) undertook a research on e-credit card use and their effects on net profit for commercial banks. The percentage of Return on Equity with the aim to assess the contribution of e-credit use that comprises number of credit cards used, operational costs and net profit ration realized. This research adopted different banks in Jordan where data and evidences obtained from secondary data. The analysis of information was done through the use of statistical package product for solutions services whereby an inferential statistics have been analyzed. This study discovered significant relationship between credit cards and net profit among financial institutions.

Vijay (2014) investigated impact of credit cards deception on the success among commercial banks in Kenya. Results denote that gold card owners were seen in Kenya Commercial Bank (KCB) with the percentage of 56\%. Most of participants are men (53\%) and women are only $47 \%$. In the context of income, therefore, gold card had the higher number of people holding credit cards, (56) which in turn lead to $33 \%$ of income achieved using credit cards. This study observed that the percentage of people who have credit cards, income gathered and quantity and percentage from credit cards change among different types of cards used.

Yahya (2015) undertook a research on influence of innovation on profitability of banking institutions in Kenya. This research had established if credit cards influence the profitability of banking institutions in Kenya, identified the role of e-banking and ascertained agent banking system on net profit in Kenya. The research' target population was 44 banking institutions that were functioning in Kenya. Information has been discussed and recapitulated in term of frequencies, percentages and pie charts. The aforementioned adopted products contribute more to the success of financial institutions.

In Rwanda, Khodaei and Sharkourloo (2013) undertake a research on the correlation between information technology facilities and performance of banking institution. They assessed the effect of five new products namely debit and credit cards, PinPad machines, online and swift branches on banking performance including Return on Asset (ROA), Return on Equity (ROE) and Net Interest Rate (NIR). The survey demonstrated the existence of a strongly correlation between POS and financial performance in Rwanda for the Bank of Kigali.

Scientific evidences from global studies both in developed and developing countries (Davenport, 2013), reiterate that clients are encouraged by this e-services owing to convenience, improving ease of utilization and in some examples, reduction of costs).

In Europe, Katsioloudes (2012) indicates that absence of Personal Computer and e-infiltration continue and access challenge related to e-banking progress in European Union. The expense for accessibility to financial services was the clear problem for computer and internet in European member states. Furthermore, 23 was deprivation of confidence in banking industry in CCs owing to previous turbulent period. These concerns are worsened with confidentiality concerns, the level of bank 'services adoption and e-banking practices in Comparison with European Union-15.

In Asia, Levine (2013) indicates that e-services emanates from cost and adequate benefits for banking institution in adopting it. Neuert (2014) gives information and facts for expenses decrease and profitability benefits as a consequence of technology transformation for European Union Banks. Nicholas (2011) demonstrated that e-banking 
reduces working expenses while enhancing client satisfaction and holding among Turkish retail banks Nzalu (2015) proposes that e-banking emanates from projects of activities expenses reduction and operational income optimization.

In sub-Sahara African, Hauner and Peiris (2015) categorized e-banking usage into two classes that comprises access technology and infrastructure linked elements with retail bank elements. One of class comprise electronic infiltration percentages, clients' knowledge towards the utilization of e-services or linked technology, habits relates to technologies, safety and confidentiality items. Another class comprises trust in banking firms, bank's culture, electronic banking habits and pushing (Indeje \& Zheng, 2010). In Nigeria, Lee and Chen (2015) discovered that trust importantly impacts attitude towards e-banking use. To stimulate its use, firms necessitate advancing methods to ameliorate client's trust in using technology. Other strategies include speed responses, assurance, responsiveness, follow up and empathy, security, suitable business, client control on transactions, order tracking and confidentiality are pertinent in e-services that influence client' satisfaction.

In East Africa, Oyugi (2014), technology (IT) gives banks the pertinent to decrease functioning costs and increases of quality of information management therefore, enabling banks to be more profitable. Mobile banking has been introduced in Tanzania by Vodacom in 2008 but its start to stimulate clients demonstrated little expected outcomes (Murgatroyd et al.(2012). The international financial corporate assessed various problems in greater depth and discussed the strategic adjustment that Vodacom has adopted to ameliorate their market position as a result, MPesa in Tanzania had five million subscribers by May, 2013. In Rwanda, Zhou et al. (2010) on the efficiency of mobile banking services in selected commercial banks in Rwanda stock of mobile banking had clearly improved, there appears to show that this type of banking had impacted the performance of commercial banks and this was the major subject of the present research.

\subsection{Theoretical Framework}

This study was carried out using Schumpeter theory of innovation diffusion theories (Yahya, 2015). These are fundamental theories that guided the present study.

Schumpeter dew a clear difference between them whole innovations give conditions for lucrative new business and bank managers who establish credit to financial the build of new investment (Nzalu, 2015). The author focused on special contribution of creating credits by banking institutions were monetary pair of inventions (Frimpong, 2010). Like private entities which had not ownership concern in newly established business them financial banking managers are capitalists who possess all dangerous (Waweru, 2012).

Waweru (2012) offers interesting allusion to innovations among banks is discovered in Schumpeter's argument on regulations governing banks of 1930. This author asserted that the 1933 law brought pertinent improvement that comprised reinforcement of federal entity to control bank's expansion of credit for theoretical objectives and division of I\&M bank Ltd and their security followers. The role of innovation was pinpointed by the researcher like (Corolyne (2011) who are capable to show how low neo-classic economists were capable of proving more explanation. The innovation and emanate from sustainable investment in physical but also intangible resources. Financial markets play pertinent contribution in activating savings, assessing projects, and managing risks, following up managers and enabling transactions.

Another relevant theory was Innovation Diffusion Theory advanced by Hernando and Nieto (2013) was adopted in assessing technology usage. Based on this model comprised 4 components of like innovations, time, channels of communicating information but also social system influence the use of technological products. Mabrouk and Mamoghli (2010) argued that personal technology use is assessed by people's perceptions concerning the absolute benefit, compatible, trainable and observable guidance of innovations and social practices.

Bell et al. (2015) assessed five general features that reliably affected the use of innovation that may be comparative benefits. Corolyne (2011) argued that difficulty, the level of innovation perception as complex to recognize and utilize for observable one, the level innovation in producing relevant information is seeable to other factors the treatability and level that financial innovations lead to practical results prior adopting e-banking (Duade \&Akingbade, 2011). The above theories enabled the researcher to establish the conceptual framework as follows:

2.3 Conceptual Framework

The conceptual framework is presented in Figure 1

This publication is licensed under Creative Commons Attribution CC BY.

http://dx.doi.org/10.29322/IJSRP.12.01.2022.p12160

www.ijsrp.org 
Independent Variable

Financial Product Innovation

Internet Banking

- Cheaper Internet Costs

- 24-hours e-banking

- Availability ICT application software

\section{Debit and Credit Cards}

- Transaction speed,

- Service cost,

- Restraint and record keeping
Dependent Variable

Financial Performance of Investments and Mortgages Bank

- Reduced Transaction \&Operation cost

- Increased net profits

- Return on Assets

\section{Mobile Banking}

- Deposits

- Withdraws

- Fund transfer between accounts

- Bill payment

\section{Moderating Variables}

- BNR policy and regulations

Figure 1 evidences the correlation between research variables. In this context, financial innovation is measured through internet banking, debit and credit cards, mobile banking. The internet banking was conceptualized by cheaper internet costs, 24-hours e-banking, availability and simplicity of ICT application software is essential.

The debit and credit cards were conceptualized by the transaction speed, service cost, and restraint and record keeping. The mobile banking was conceptualized using the deposits, withdraws, fund transfer between accounts and bill payment.

The dependent variable was assessed using the reduced transaction \&operation cost, increased net profits and return on assets. Both dependent and independent variables were moderated using intervening variables in the context of BNR policy and regulations. 


\section{RESEARCH METHODOLOGY}

This study used the descriptive method with both qualitative and quantitative approaches. This guaranteed that understanding is improved by incorporating various methods of knowing. The sample size of 193 was drawn from 370 employees (Investments and Mortgages Bank, 2020) using a simple random sampling and purposive sampling techniques. For quantitative data analysis, descriptive and inferential statistics were used while qualitative data analysis applied content analysis.

\section{RESUlTS AND DisCUSSION}

4.1 Effects of Internet Banking on Financial Performance of I\&M Bank

Table 1 presents the views on whether Internet Banking affect Financial Performance of I\&M Bank.

Table 1: Correlation Analysis between Internet Banking and Financial Performance of I\&M Bank

\begin{tabular}{|c|c|c|c|c|c|c|c|}
\hline & & $\begin{array}{l}\text { Cheaper } \\
\text { Internet } \\
\text { Costs }\end{array}$ & $\begin{array}{l}\text { 24-hours } \\
\text { banking }\end{array}$ & $\begin{array}{l}\text { Availability } \\
\text { e- ICT } \\
\text { application } \\
\text { software } \\
\end{array}$ & $\begin{array}{l}\text { Reduced } \\
\text { Transaction } \\
\text { \&Operation } \\
\text { cost }\end{array}$ & $\begin{array}{l}\text { Increased } \\
\text { net profits }\end{array}$ & $\begin{array}{l}\text { Return on } \\
\text { Assets }\end{array}$ \\
\hline \multirow[t]{3}{*}{$\begin{array}{l}\text { Cheaper } \\
\text { Costs }\end{array}$} & $\begin{array}{l}\text { Pearson } \\
\text { Correlation }\end{array}$ & 1 & $0.196^{* *}$ & -0.036 & -0.139 & 0.120 & 0.107 \\
\hline & Sig. (2-tailed) & & 0.008 & 0.628 & 0.060 & 0.107 & 0.151 \\
\hline & $\mathrm{N}$ & 182 & 182 & 182 & 182 & 182 & 182 \\
\hline \multirow[t]{3}{*}{ 24-hours e-banking } & $\begin{array}{l}\text { Pearson } \\
\text { Correlation }\end{array}$ & $.196^{* *}$ & 1 & -0.062 & 0.026 & -0.142 & 0.002 \\
\hline & Sig. (2-tailed) & 0.008 & & 0.403 & .728 & 0.057 & 0.983 \\
\hline & $\mathrm{N}$ & 182 & 182 & 182 & 182 & 182 & 182 \\
\hline \multirow{3}{*}{$\begin{array}{l}\text { Availability ICT I } \\
\text { application software }\end{array}$} & $\begin{array}{l}\text { Pearson } \\
\text { Correlation }\end{array}$ & -0.036 & -0.062 & 1 & 0.082 & $0.177^{*}$ & 0.058 \\
\hline & Sig. (2-tailed) & .628 & .403 & & .271 & .017 & .435 \\
\hline & $\mathrm{N}$ & 182 & 182 & 182 & 182 & 182 & 182 \\
\hline \multirow{3}{*}{$\begin{array}{l}\text { Reduced } \\
\text { Transaction } \\
\text { \&Operation cost }\end{array}$} & $\begin{array}{l}\text { Pearson } \\
\text { Correlation }\end{array}$ & -.139 & 0.026 & 0.082 & 1 & -0.043 & -0.068 \\
\hline & Sig. (2-tailed) & 0.060 & 0.728 & 0.271 & & 0.566 & 0.363 \\
\hline & $\mathrm{N}$ & 182 & 182 & 182 & 182 & 182 & 182 \\
\hline \multirow[t]{3}{*}{ Increased net profits } & $\begin{array}{l}\text { Pearson } \\
\text { Correlation }\end{array}$ & 0.120 & -0.142 & $.177^{*}$ & -0.043 & 1 & -0.040 \\
\hline & Sig. (2-tailed) & 0.107 & 0.057 & 0.017 & 0.566 & & 0.593 \\
\hline & $\mathrm{N}$ & 182 & 182 & 182 & 182 & 182 & 182 \\
\hline \multirow[t]{3}{*}{ Return on Assets } & $\begin{array}{l}\text { Pearson } \\
\text { Correlation }\end{array}$ & 0.107 & 0.002 & 0.058 & -0.068 & -0.040 & 1 \\
\hline & Sig. (2-tailed) & 0.151 & 0.983 & 0.435 & 0.363 & 0.593 & \\
\hline & $\mathrm{N}$ & 182 & 182 & 182 & 182 & 182 & 182 \\
\hline
\end{tabular}

**. Correlation is significant at the 0.01 level (2tailed). 


\begin{tabular}{|c|c|c|c|c|c|c|c|}
\hline & & $\begin{array}{l}\text { Cheaper } \\
\text { Internet } \\
\text { Costs }\end{array}$ & $\begin{array}{l}\text { 24-hours } \\
\text { banking }\end{array}$ & $\begin{array}{l}\text { Availability } \\
\text { e- ICT } \\
\text { application } \\
\text { software }\end{array}$ & $\begin{array}{l}\text { Reduced } \\
\text { Transaction } \\
\text { \&Operation } \\
\text { cost }\end{array}$ & $\begin{array}{l}\text { Increased } \\
\text { net profits }\end{array}$ & $\begin{array}{l}\text { Return on } \\
\text { Assets }\end{array}$ \\
\hline \multirow[t]{3}{*}{$\begin{array}{l}\text { Cheaper } \\
\text { Costs }\end{array}$} & $\begin{array}{l}\text { Pearson } \\
\text { Correlation }\end{array}$ & 1 & $0.196^{* *}$ & -0.036 & -0.139 & 0.120 & 0.107 \\
\hline & Sig. (2-tailed) & & 0.008 & 0.628 & 0.060 & 0.107 & 0.151 \\
\hline & $\mathrm{N}$ & 182 & 182 & 182 & 182 & 182 & 182 \\
\hline \multirow[t]{3}{*}{ 24-hours e-banking } & $\begin{array}{l}\text { Pearson } \\
\text { Correlation }\end{array}$ & $.196^{* *}$ & 1 & -0.062 & 0.026 & -0.142 & 0.002 \\
\hline & Sig. (2-tailed) & 0.008 & & 0.403 & .728 & 0.057 & 0.983 \\
\hline & $\mathrm{N}$ & 182 & 182 & 182 & 182 & 182 & 182 \\
\hline \multirow[t]{3}{*}{$\begin{array}{l}\text { Availability ICT } \\
\text { application software }\end{array}$} & $\begin{array}{l}\text { Pearson } \\
\text { Correlation }\end{array}$ & -0.036 & -0.062 & 1 & 0.082 & $0.177^{*}$ & 0.058 \\
\hline & Sig. (2-tailed) & .628 & .403 & & .271 & .017 & .435 \\
\hline & $\mathrm{N}$ & 182 & 182 & 182 & 182 & 182 & 182 \\
\hline \multirow{3}{*}{$\begin{array}{l}\text { Reduced } \\
\text { Transaction } \\
\text { \&Operation cost }\end{array}$} & $\begin{array}{l}\text { Pearson } \\
\text { Correlation }\end{array}$ & -.139 & 0.026 & 0.082 & 1 & -0.043 & -0.068 \\
\hline & Sig. (2-tailed) & 0.060 & 0.728 & 0.271 & & 0.566 & 0.363 \\
\hline & $\mathrm{N}$ & 182 & 182 & 182 & 182 & 182 & 182 \\
\hline \multirow[t]{3}{*}{ Increased net profits } & $\begin{array}{l}\text { Pearson } \\
\text { Correlation }\end{array}$ & 0.120 & -0.142 & $.177^{*}$ & -0.043 & 1 & -0.040 \\
\hline & Sig. (2-tailed) & 0.107 & 0.057 & 0.017 & 0.566 & & 0.593 \\
\hline & $\mathrm{N}$ & 182 & 182 & 182 & 182 & 182 & 182 \\
\hline \multirow[t]{3}{*}{ Return on Assets } & $\begin{array}{l}\text { Pearson } \\
\text { Correlation }\end{array}$ & 0.107 & 0.002 & 0.058 & -0.068 & -0.040 & 1 \\
\hline & Sig. (2-tailed) & 0.151 & 0.983 & 0.435 & 0.363 & 0.593 & \\
\hline & $\mathrm{N}$ & 182 & 182 & 182 & 182 & 182 & 182 \\
\hline
\end{tabular}

*. Correlation is significant at the 0.05 level (2tailed).

Correlation analysis indicated a positive significant correlation between availability and simplicity of ICT application and the increase in net profits $\left(\mathrm{r}=0.177^{*}, \mathrm{p}=0.017\right)$ since the $\mathrm{p}$ value is less than 0.05 indicating that the availability and simplicity of ICT application leads to the increase in net profits. However, there were insignificant correlation between cheaper internet costs and profits $(\mathrm{r}=0.120, \mathrm{p}=0.107)$ and cheaper internet costs and return on assets $(r=0.107, p=0.151)$. These correlations were positively not correlated since the $\mathrm{p}$ value was $>0.05$ indicating that an increase in cheaper internet did not reflect an increase of profit and return on asset and vice versa.

Moreover, results insignificant correlation between 24-hours e-banking and the reduction transaction and operation costs $(\mathrm{r}=0.026, \mathrm{p}=0.728)$. This correlation was statistically not significant since the $\mathrm{p}$ value was $>0.05$ indicating that an increase in cheaper internet did not affect operation and transaction cost and vice versa. Contrary to a significant correlation between 24-hours e-banking and profits $(\mathrm{r}=-0.142, \mathrm{p}=0.057)$ and 24-hours e-banking and return on assets $(\mathrm{r}=0.002, \mathrm{p}=0.982)$. These correlations were correlated since the $\mathrm{p}$ value was $<0.05$ indicating that an increase in cheaper internet led to an increase of profit and return on asset and vice versa.

Findings demonstrated positive insignificant correlations between availability ICT application software and the reduction transaction and operation costs $(\mathrm{r}=0.082, \mathrm{p}=0.271)$, availability ICT application software and return on assets $(\mathrm{r}=0.058, \mathrm{p}=0.435)$. These correlations were statistically not significant since the $\mathrm{p}$ value was $>0.05$ indicating that an 
increase in availability ICT application software did not affect operation and transaction cost and vice versa. Contrary to a significant correlation between availability ICT application software and assets $(r=0.117, p=0.017)$. These correlations were positively correlated with return on assets since the p value was $<0.05$ indicating that an increase in cheaper internet led to an increase of profit and return on asset and vice versa.

\subsection{Effects of Debit and Credit Cards on financial performance of I\&M Bank in Rwanda.}

Table 2 depicts views on Effects of Debit and Credit Cards on financial performance of I\&M Bank in Rwanda.

Table 2: Effects of Debit and Credit Cards on financial performance of I\&M Bank in Rwanda.

\begin{tabular}{|c|c|c|c|c|c|c|c|}
\hline & & $\begin{array}{l}\text { Transaction } \\
\text { speed, }\end{array}$ & Service cost & $\begin{array}{l}\text { Restraint } \\
\text { and record } \\
\text { keeping }\end{array}$ & $\begin{array}{l}\text { Transaction } \\
\text { \&Operation } \\
\text { cost }\end{array}$ & Net profits & $\begin{array}{l}\text { Return on } \\
\text { assets }\end{array}$ \\
\hline \multirow[t]{3}{*}{ Transaction speed } & $\begin{array}{l}\text { Pearson } \\
\text { Correlation }\end{array}$ & 1 & -0.007 & 0.109 & 0.090 & 0.059 & 0.034 \\
\hline & Sig. (2-tailed) & & 0.921 & 0.142 & .227 & 0.429 & 0.652 \\
\hline & $\mathrm{N}$ & 182 & 182 & 182 & 182 & 182 & 182 \\
\hline \multirow[t]{3}{*}{ Service cost } & $\begin{array}{l}\text { Pearson } \\
\text { Correlation }\end{array}$ & -0.007 & 1 & 0.228 & 0.025 & 0.053 & -0.042 \\
\hline & Sig. (2-tailed) & 0.921 & & 0.002 & 0.733 & 0.476 & 0.570 \\
\hline & $\mathrm{N}$ & 182 & 182 & 182 & 182 & 182 & 182 \\
\hline \multirow[t]{3}{*}{$\begin{array}{l}\text { Restraint and record } \\
\text { keeping }\end{array}$} & $\begin{array}{l}\text { Pearson } \\
\text { Correlation }\end{array}$ & 0.109 & 0.228 & 1 & 0.047 & $-0.158^{*}$ & 0.020 \\
\hline & Sig. (2-tailed) & 0.142 & 0.002 & & 0.526 & 0.033 & 0.791 \\
\hline & $\mathrm{N}$ & 182 & 182 & 182 & 182 & 182 & 182 \\
\hline \multirow[t]{3}{*}{$\begin{array}{l}\text { Transaction } \\
\text { \&Operation cost }\end{array}$} & $\begin{array}{l}\text { Pearson } \\
\text { Correlation }\end{array}$ & 0.090 & 0.025 & 0.047 & 1 & -0.043 & -0.068 \\
\hline & Sig. (2-tailed) & .227 & 0.733 & 0.526 & & 0.566 & 0.363 \\
\hline & $\mathrm{N}$ & 182 & 182 & 182 & 182 & 182 & 182 \\
\hline \multirow[t]{3}{*}{ Net profits } & $\begin{array}{l}\text { Pearson } \\
\text { Correlation }\end{array}$ & 0.059 & 0.053 & $-0.158^{*}$ & -0.043 & 1 & -0.040 \\
\hline & Sig. (2-tailed) & 0.429 & 0.476 & 0.033 & 0.566 & & 0.593 \\
\hline & $\mathrm{N}$ & 182 & 182 & 182 & 182 & 182 & 182 \\
\hline \multirow[t]{3}{*}{ Return on assets } & $\begin{array}{l}\text { Pearson } \\
\text { Correlation }\end{array}$ & 0.034 & -0.042 & 0.020 & -0.068 & -0.040 & 1 \\
\hline & Sig. (2-tailed) & 0.652 & 0.570 & 0.791 & 0.363 & 0.593 & \\
\hline & $\mathrm{N}$ & 182 & 182 & 182 & 182 & 182 & 182 \\
\hline
\end{tabular}

**. Correlation is significant at the 0.01 level (2tailed).

*. Correlation is significant at the 0.05 level (2tailed).

Transaction speed and transaction and operation cost $(\mathrm{r}=0.090 * *, \mathrm{p}=0.227)$, transaction speed and net profit $\left(\mathrm{r}=0.059^{*}, \mathrm{p}=0.0429\right)$, and between transaction speed and return on asset $(\mathrm{r}=0.034, \mathrm{p}$ value $=0.652)$ were not correlated. Given that the $\mathrm{p}$ value was $>0.05$ suggesting that an increase in debit and credit cards did not affect transaction and operation cost and net profit. 
Results for the correlation between the reduction of service cost and operation cost $(r=0.228, p=0.002)$ was statistically significant. However, the reduction of service cost and net profit $(\mathrm{r}=0.025, \mathrm{p}=0.733)$, and between reduction of service and return on asset $(r=-0.042, p$ value $=0.570)$ were not correlated. Given that the $\mathrm{p}$ value was $>0.05$, the increase in debit and credit cards did not affect transaction and operation cost and net profit.

Results for the correlation between the restraint and record keeping and operation cost $(r=0.027, p=0.526)$ and between restraint and record keeping and return on asset $(r=-0.020, p$ value $=0.791)$ were not correlated. Given that the $\mathrm{p}$ value was $>0.05$, the increase in debit and credit cards did not affect transaction and operation cost and net profit. However, restraint and record keeping and net profit were statistically correlated $(r=0.158, p=0.33)$, since the $p$ value was $<0.05$.

\subsection{Effects of Mobile Banking on Financial Performance of I\&M Bank, Rwanda}

Table 3 illustrates the views on Effects of Mobile Banking on Financial Performance of I\&M Bank, Rwanda 
Table 1: Effects of Mobile Banking on Financial Performance of I\&M Bank, Rwanda

\begin{tabular}{|c|c|c|c|c|c|c|c|c|}
\hline & & $\begin{array}{l}\text { Quick } \\
\text { deposits }\end{array}$ & $\begin{array}{l}\text { Safe } \\
\text { withdraws }\end{array}$ & $\begin{array}{l}\text { Easy fund } \\
\text { transfer } \\
\text { between } \\
\text { accounts }\end{array}$ & $\begin{array}{l}\text { Bill } \\
\text { payment }\end{array}$ & $\begin{array}{l}\text { Transaction } \\
\& \text { Operation } \\
\text { cost }\end{array}$ & Net profits & $\begin{array}{l}\text { Return on } \\
\text { assets }\end{array}$ \\
\hline \multirow[t]{3}{*}{ Quick deposits } & $\begin{array}{l}\text { Pearson } \\
\text { Correlation }\end{array}$ & 1 & 0.212 & 0.263 & 0.014 & 0.333 & 0.044 & -0.024 \\
\hline & Sig. (2-tailed) & & 0.004 & 0.000 & 0.846 & 0.000 & 0.555 & 0.750 \\
\hline & $\mathrm{N}$ & 182 & 182 & 182 & 182 & 182 & 182 & 182 \\
\hline \multirow[t]{3}{*}{ Safe withdraws } & $\begin{array}{l}\text { Pearson } \\
\text { Correlation }\end{array}$ & 0.212 & 1 & 0.203 & 0.082 & 0.136 & -0.012 & 0.017 \\
\hline & Sig. (2-tailed) & 0.004 & & 0.006 & 0.274 & 0.067 & 0.876 & 0.816 \\
\hline & $\mathrm{N}$ & 182 & 182 & 182 & 182 & 182 & 182 & 182 \\
\hline \multirow[t]{3}{*}{$\begin{array}{l}\text { Fund transfer } \\
\text { between accounts }\end{array}$} & $\begin{array}{l}\text { Pearson } \\
\text { Correlation }\end{array}$ & 0.263 & 0.203 & 1 & 0.280 & 0.037 & 0.016 & 0.163 \\
\hline & Sig. (2-tailed) & 0.000 & 0.006 & & 0.000 & 0.619 & 0.829 & 0.028 \\
\hline & $\mathrm{N}$ & 182 & 182 & 182 & 182 & 182 & 182 & 182 \\
\hline \multirow[t]{3}{*}{ Bill payment } & $\begin{array}{l}\text { Pearson } \\
\text { Correlation }\end{array}$ & 0.014 & 0.082 & 0.280 & 1 & -0.068 & -0.022 & 0.115 \\
\hline & Sig. (2-tailed) & 0.846 & 0.274 & 0.000 & & 0.361 & 0.767 & 0.121 \\
\hline & $\mathrm{N}$ & 182 & 182 & 182 & 182 & 182 & 182 & 182 \\
\hline \multirow[t]{3}{*}{$\begin{array}{l}\text { Transaction } \\
\& \text { Operation cost }\end{array}$} & $\begin{array}{l}\text { Pearson } \\
\text { Correlation }\end{array}$ & 0.333 & 0.136 & 0.037 & -0.068 & 1 & -0.043 & -0.068 \\
\hline & Sig. (2-tailed) & 0.000 & 0.067 & 0.619 & 0.361 & & 0.566 & 0.363 \\
\hline & $\mathrm{N}$ & 182 & 182 & 182 & 182 & 182 & 182 & 182 \\
\hline \multirow[t]{3}{*}{ Net profits } & $\begin{array}{l}\text { Pearson } \\
\text { Correlation }\end{array}$ & 0.044 & -0.012 & 0.016 & -0.022 & -0.043 & 1 & -0.040 \\
\hline & Sig. (2-tailed) & 0.555 & -0.876 & 0.829 & 0.767 & 0.566 & & 0.593 \\
\hline & $\mathrm{N}$ & 182 & 182 & 182 & 182 & 182 & 182 & 182 \\
\hline \multirow[t]{3}{*}{ Return on assets } & $\begin{array}{l}\text { Pearson } \\
\text { Correlation }\end{array}$ & -0.024 & 0.017 & $0.163^{*}$ & 0.115 & -0.068 & -0.040 & 1 \\
\hline & Sig. (2-tailed) & 0.750 & 0.816 & 0.028 & 0.121 & 0.363 & 0.593 & \\
\hline & $\mathrm{N}$ & 182 & 182 & 182 & 182 & 182 & 182 & 182 \\
\hline
\end{tabular}

**. Correlation is significant at the 0.01 level

(2-tailed).

*. Correlation is significant at the 0.05 level

(2-tailed).

Significant positive correlations were found between quick deposits transaction and operation cost $(\mathrm{r}=0.333$, $\mathrm{p}=.0 .000)$ given that the $\mathrm{p}$ value was $<0.05$ suggesting that increase in quick deposits in transaction and operational cost and the vice versa. However, quick deposits was not statistically significant with net profits $(r=0.750, p=0.024)$, quick deposits was not statistically significant with net profits $(\mathrm{r}=0.750, \mathrm{p}=0.024)$, save withdrawn was statistically significant with transaction and operational costs $(\mathrm{r}=0.136, \mathrm{p}=0.067)$, save withdrawn was not statistically significant with net profit $(\mathrm{r}=0.012, \mathrm{p}=0.876)$, save withdrawn was statistically significant with return on asset $(\mathrm{r}=0.017, \mathrm{p}=0.816)$, since the $\mathrm{p}$ value is more than 0.05 . 
Fund transfer between accounts was not statistically significant with transaction and operational costs $(r=0.037$, $\mathrm{p}=0.619)$, fund transfer between accounts was not statistically significant with net profit $(\mathrm{r}=0.016), \mathrm{p}=0.829)$. Contrary to fund transfer between accounts which was statistically significant with return on asset $(r=0.163, p=0.028)$, since the $\mathrm{p}$ value is less than 0.05 .

Fund transfer between accounts was not statistically significant with transaction and operational costs $(r=0.068$, $\mathrm{p}=0.361$ ), fund transfer between accounts was not statistically significant with net profit $(\mathrm{r}=0.027), \mathrm{p}=0.367)$, and for fund transfer between accounts which was statistically significant with return on asset $(\mathrm{r}=0.115, \mathrm{p}=0.121)$.

\section{DISCUSSION OF THE RESEARCH FINDINGS}

Results on the effect of internet banking on financial performance of Investment and Mortgage Bank in Rwanda contract with the findings of Adeoti (2021) who focused on the use of internet banking was secured and adequate. Internet banking has made settlement of bills in banking system easy and saver. The benefits had emanated from a phenomenon growth. Meanwhile, the benefits of safe and suitable of internet had regrettably been reduced by the frauds that were committed by plastic money. An increase in number of clients and had improved the tendency of falsified practices.

Results on the effect of debit and credit cards on financial performance of Investment and Mortgage Bank in Rwanda did not contradict previous researches such as Rajasekar (2014) investigated determinants influencing the utilization of credit cards among commercial banks. This scholar used a sample size of 23 employees and the processing of gathering information was done using questionnaires and participants was composed of $52 \%$ of men and $48 \%$ of women. It was revealed that managers had credit cards whereas most of middle staff and workers did not possess credit cards. The study revealed that determinants of using credit cards are card deception, understanding protests, criticisms. Results evidenced that financial product innovation has a positive to financial performance equal to 0.964 and the significance value is 0.000 is less than 0.01 meaning that variables are correlated and that financial system contributed to the profitability of I\&M Bank.

Results on the effect of mobile banking on financial performance of Investment and Mortgage Bank in Rwanda since it is line with findings of This study is relevant with the observation of Hauner and Peiris (2015) categorized ebanking usage into two classes that comprises access technology and infrastructure linked elements. For instance, electronic infiltration percentage, clients' knowledge in utilizing information and linked technology, habits towards technologies, safety and privacy items. A correlation of antecedents is adequately discovered in scientific and empirical ways. A regression analysis was done to produce a model summary, analysis of variance and coefficient model for all dependent variables.

\section{CONCLUSION AND RECOMMENDATIONS}

To the first objective, the study concludes that internet banking product adopted included cheaper internet costs, 24 hours e-banking services and availability and simplicity of ICT application software is essential. This internet banking product innovation is more likely to contribute to the profitability of I\&M Bank in Rwanda. This implies that improvement in internet banking leads to financial performance of I\&M Bank

To the second objective, the study concludes that the debit and credit cards product introduced by I\&M Bank are based on transaction speed, service cost, convenience, security, restraint and record keeping. Debit and Credit Cards had a positive correlation with the reduction of transaction and operation cost, and the increase of net profit.

To the third objective, the study established that mobile baking product introduced by I\&M Bank include deposits volume, withdraws volume, fund transfer between accounts and bill payment. Significant positive correlations were found between mobile banking and the reduced transaction \&operation cost and increased net profits.

The study concludes that all innovations implemented have significantly contributed to the overall performance of the bank as evidenced by the increase in customer base (Number of customers-new accounts-growth in deposits), customer satisfaction rate (customer satisfaction survey), improved efficiencies and the growth in profitability (increase of $34 \%$ in profits before tax from 7.1 billion to 10.8 billion). 


\section{REFERENCES}

[1] Adeoti J.A. (2011). Automated Teller Machine (ATM) Frauds in Nigeria: The Way Out. Journal of Social Sciences, 27(1): 53-58.

[2] Al-Hawari, M. A., Hartley, N., \& Ward, T. (2015). Measuring banks automated service quality: A confirmatory factor analysis approach. Marketing Bulletin, 16(1), $1-19$.

[3] Bell, S. J., Auh, S., \& Smalley, K. (2015). Customer relationship dynamics: Service quality, and customer loyalty in the context of varying levels of customer expertise and switching costs. Journal of the Academy of Marketing Science, 169- 183

[4] Corolyne, N., (2011). Financial Innovation and its effects on financial performance on the commercial banks in Kenya, Unpublished MBA Project, University of Nairobi

[5] Davenport, T. (2013). Process Innovation: Reengineering Work through Information Technology, Boston, USA: Harvard Business School Press.

[6] Duade, Y. B. \&Akingbade, R. (2011). Equity and Bond Portfolio Analyst at Asset Management Corporation of Nigeria, Financial Service Industry, Lagos, Nigeria: Ibadan University Press.

[7] Frimpong, J.M. (2010). „Investigating efficiency of Ghana banks: A non-parametric approach “, American Journal of Scientific Research, 8(7), 874-880.

[8] Hauner, D., \& Peiris, S. J. (2015). Bank Efficiency and Competition in Low-Income Countries: The Case of Uganda. International Monetary Fund Working Paper $\mathrm{WP} / 15 / 240$

[9] Hernando, I. \& Nieto, M. J. (2016). Is the internet delivery channel changing banks' performance? The case of Spanish banks. Journal of Banking \& Finance, 31(4), 1083-1099.

[10] Hernando, I., \& Nieto, M.J. (2013). Is the internet delivery channel changing banks’ performance? The case of Spanish banks. Journal of Banking \& Finance, 31(4), 1083-1099.

[11] Indeje, W., \& Zheng, Q. (2010). Organizational culture and information systems implementation: A structuration theory perspective, Sprouts: Working Papers on Information Systems 10(27).

[12] Investments \& Mortgages Bank (I\&M Bank) (2019). Annual report and financial statements for the year ended 2018/2019.Kigali- Rwanda

[13] Jibril, A.K. \& Nwanmou, C.N, (2012). Research Method in Social Sciences and Education. Umuahia, Pakistan: Cijeh Concept Publisher.

[14] Khodaei,V, M., \& Shakourloo, A. (2013). A study on relationship between information technology facilities and performance of banking industry. Management Science Letters,3(3), 833-838.

[15] Lee, C., \& Chen, W. (2015). The effects of internal marketing and organizational culture on knowledge management in the information technology industry. International Journal of Management, 22(4), 661 - 27.

[16] Mabrouk, A., \& Mamoghli, C. (2010). Dynamic of financial innovation and performance of banking firms: Context of an emerging banking industry. International Research Journal of Finance and Economics, 5, 2010

[17] Mckee, J. (2013). Applying Principles from IT Architecture to Strategic Business Planning. United States of America: IGI Global.

[18] Mills, A. J., Helms, J. C., \& Bratton, J. (2016). Organizational Behavior in a Global Context. Canada: The Authors.

[19] Murayireko, N (2011). Competitive manufacturing management, Tata McGraw-Hill

[20] Murgatroyd. P., Dry,J., Power,T. \& Postgate W. (2012). Rwanda Financial Sector Development Program, First initiative, Kigali, Rwanda.

[21] Mussiime A. V. and Biyaki N. (2010). Banking: The IT Paradox. McKinsey .Quarterly 1: 45-51.

[22] Muthoni, M. G. (2013). The effect of financial innovation of financial performance of insurance companies in Kenya. Unpublished MBA Project, Nairobi, Kenya: University of Nairobi

[23] National Bank of Rwanda (2017). Annual report and financial statements for the year ended 2016/2017.Kigali Rwanda

[24] Ndikuriyo. N. S (2018). Product innovation and Financial Performance of Commercial Banks in Rwanda, A case study of Banque Populaire du Rwanda Ltd, MBA Thesis, Mount Kenya University, 2018; HF 5415.N35/2018.

[25] Neuert, J. (2014). Contemporary Approaches of International Business Management, Economics and Social Research. Berlin: Epubli GmbH.

[26] Ngari, J. M., \& Muiruri, J. K., (2014). Effects of financial innovation on the financial performance of commercial banks in Kenya, International Journal of Humanities \& Social Sciences, 4 (7), 10- 13

[27] Ntuite R.S (2015), Analysis of Financial Performance of Commercial Banks in Rwanda, A case study of I\&M BankLtd;

[28] Nyangosi, R., \& Arora J. (2010), Emergence of Information Technology in the Kenyan banking Sector: An empirical study. Khalsa College, G.N.D University Amritsar143005, (Pb) India.

[29] Nzalu, F.M. (2015). An Assessment of the Factors Affecting the Growth in Real Estate Investment in Kenya, MBA Project, University of Nairobi.

[30] Okibo, B. W., \& Wario, A. Y. (2014). Effects of e-banking on growth of customer base in Kenyan banks. International journal of research in management \& business studies, 1(1), 78-84.

[31] Okiro.K.(2013).The Impact of Mobile and Internet Banking on Performance of Financial Institutions in Kenya, unpublished MBA Project, Nairobi, Kenya: University of Nairobi

[32] Rajasekar, J. (2014). Factors affecting Effective Strategy Implementation in a Service Industry: A Study of Electricity Distribution Companies in the Sultanate of Oman. International Journal of Business and Social Science, 9(1), 15.

[33] Santos, J. (2013). E-service quality: A model of virtual service quality dimensions. Managing service quality: An international journal, 13(3), 233-246.

[34] Shin, K.Y. (2013). The Executor of Integrated Marketing Communications Strategy: Marcom Manager's Working Model. USA: Springer Berlin Heidelberg.

[35] Swanson, E. B., \& Ramiller, N. C. (2014). Innovating mindfully with information technology. MIS Quarterly, 28(4), 553-583.

[36] Tuyishime, R, Memba.Fand Mbera. Z (2015). The effects of deposits Mobilization on financial performance in commercial banks in Rwanda. A case of I\&M Bank Rwanda Limited, International Journal of Small Business and Entrepreneurship Research 3, (6) 44-71.

[37] Vijay, R. (2014). Technology Adoption in Developing Countries, UK: Oxford University Press.

[38] Waweru, E. W. (2012). The effect of financial innovations on risk management of commercial banks in Kenya. Unpublished MBA project, Nairobi, Kenya: University of Nairobi.

[39] Yahya, Z. A. (2015) Privatization and Firm Performance: An Empirical Study of Selected Privatized Firms in Nigeria, Mediterranean Journal of Social Sciences, 8 (3) 11-46.

[40] Zhou, T., Lu, Y.\& Wang, B. (2010). Integrating TTF and UTAUT to explain mobile banking user adoption. Computers in Human Behavior, $26(4), 760-767$. 


\section{AUTHORS}

First Author - Theogene Ntirenganya, School of Business and Economics, Mount Kenya University Kigali, Rwanda

Second Author - Dr. Mercyline Kamande, School of Business and Economics, Mount Kenya University, Kigali, Rwanda

Correspondence Author - theos80@yahoo.fr 